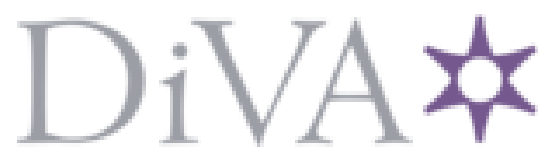

http://www.diva-portal.org

This is the published version of a paper published in Vård $i$ Norden.

Citation for the original published paper (version of record):

Lidell, E., Hildingh, C., Arvidsson, B. (2008)

Awareness in research supervision: a single subject study.

Vård i Norden, 28(2): 23-26

Access to the published version may require subscription.

N.B. When citing this work, cite the original published paper.

Permanent link to this version:

http://urn.kb.se/resolve?urn=urn:nbn:se:hh:diva- 1563 


\title{
Awareness in research supervision; a single subject study
}

\author{
Evy Lidell, RNT, PhD - Cathrine Hildingh, RNT, PhD - Barbro Arvidsson, RNT, PhD
}

\section{ABSTRACT}

Theoretically, one part of supervision is the direct object i.e. what can be learnt, another part is the indirect object aiming at how the learning process is constituted and influenced by both the doctoral student and his/her supervisor. Emphasising both the what and the how object of learning as well as their interrelationship may be an important factor for the development of the role of supervisor in research. The aim of this study was to describe supervision of doctoral students from the perspective of a research supervisor. Interview data were analysed in accordance with content analysis. The result showed that research supervision had a latent content of awareness of underlying structures and the preconditions for learning that became visible through self-appraisal, orientation towards a goal, in the interaction and the performance of an art. Awareness was a cornerstone in research supervision that enabled both the what and the how aspect of learning.

\section{KEY WORDS: Awareness; Content analysis; Research supervision}

\section{Introduction}

During the past five years, many nurses in Sweden have successfully defended their doctoral thesis. Continued development is dependent on nurses having the opportunity to enrol as doctoral students, which presupposes that suitably qualified persons are available to undertake the task of supervision and given the opportunity to expand their role (1). There are many aspects to consider before accepting the role of research supervisor (2). Primary is that research supervision not only concerns knowledge, but the relationship between a doctoral student and a supervisor, which can be of a considerable duration (3). During the process, the doctoral student is expected to acquire the insight and knowledge required to be able to work as an independent researcher (4). In order to achieve this, there is a need for an object, i.e. something to learn, the content of which has a natural focus but this direct object is just one part of supervision. There is also an indirect object aiming at how the learning in itself or the learning process is constituted and influenced by both the doctoral student and his/her supervisor (5). Emphasising both the what and the how object of learning as well as their interrelationship may be an important factor for the development of the role of supervisor in research. Studies focusing on research supervision have revealed problems concerning the supervisory role and the relationship between supervisor and supervisee (6-11). The problems are related to the differing background and demographic status of doctoral students, such as gender, age, family situation, work, financial position and social conditions as well as the supervisor's ability to deal with these during the various phases of the thesis work (12-13). Bergenheim (7) argues that research supervision implies too close a collaboration between supervisor and doctoral student, which means that the design, content and quality of the thesis are overly influenced by the supervisor's ambition, knowledge and personal qualities. Few studies deal with qualitative research from a supervisor perspective. However, such studies are necessary, as they can serve as a point of departure for the development of the pedagogy of research supervision. The aim of this study was therefore to describe supervision of doctoral students from the supervisor perspective.

\section{Method}

This single case study, which has a descriptive design with a qualitative approach, was performed at a university in southern Sweden.

\section{Informants/ethical considerations}

Telephone contact was made with a research supervisor experienced in pedagogic. She was informed about the motive and aim of the study and asked to participate, on the understanding that her decision could be given by telephone at a later date. Two days later the supervisor indicated willingness to participate, after which the information was provided that participation was voluntary and that confidentiality was guaranteed. The supervisor then agreed to give written consent and a time and place for the interview was decided.

\section{Data collection}

The interview was conducted in the interviewer's office and focused on the informant's perceptions of supervising doctoral students. The interview concentrated on one main question: «What is your perception of being a research supervisor?» and continued with questions that related to the what and how aspects. In addition, some questions were posed with the intention of clarifying the supervisor's statements. The interview, which lasted one hour and fifteen minutes, was audio-taped and transcribed verbatim by EL. After the interview, time was allowed for reflection in order to give the informant the opportunity to discuss her perception of being interviewed and to ensure that she had no objection to the data being used.

\section{Data analysis}

The data were analysed in accordance with content analysis (14). Initially, the entire interview text was read on two occasions in order to become more familiar with the data, after which text related to perceptions of supervision, so called meaning units, was marked. The condensed units were coded, and categories encompassing the content of supervision seen from the perspective of the research supervisor were formulated. Based on these categories, a theme describing the underlying meaning of the text, i.e. the latent content, was developed. The interviewer, herself a research supervisor, was aware that her preunderstanding could influence the analysis, which is why the informant was asked to assess the reasonableness of the results. The trustworthiness was tested by comparing the categories to the empirical data.

\section{Results}

The analysis resulted in four categories: self-appraisal, orientation towards a goal, interaction, and performance of an art, which describe the content of research supervision as perceived by a research supervisor. The latent content was formulated into the theme; awareness of underlying structures and preconditions for learning. 


\section{Self-appraisal}

This category included ability, humanistic outlook, gains as well as experiences of threat. The respondent's personal ability was appraised on the basis of thoughts, such as: is my own knowledge of use to the doctoral student and can I manage the supervisor assignment and the responsibility involved? The supervisor's personal merits were judged as her ability to detect connections. The informant described the ability to see whether or not the doctoral student was moving in the direction of a good product even when the process was slow and difficult to handle. Another gain was the ability to manage learning based on a humanistic outlook on the human being. The motive behind acceptance of the assignment was gains in the form of a stimulus that promoted continuous learning and the doctoral students' development in the scientific area. Limitations mostly concerned the informant's scientific knowledge. Self-confidence could be diminished, which was associated with the informant undergoing learning. The idea that the doctoral student could become more knowledgeable than the supervisor in the use of methods was perceived as a threat. Educational conditions were deemed to have improved considerably since the interviewer's own doctoral studies.

«This about promoting good processes, learning, pedagogical aspects - I've got that. I know it. With my scientific competence, I'm an expert in that area ... I am also learning».

«That is, I have a critical attitude to my own role, my position and responsibility.»

\section{Orientation towards a goal}

The informant focused on the product of the doctoral student's work and her research competence. The product should be of a high quality and the doctoral student should develop into a competent and independent researcher. The goal also included making the doctoral student a competent representative of the knowledge area.

"The most important thing is to guide the doctoral student to achieve a good product».

«For the doctoral student, the product is paramount but I also want him/her to possess broad competence. After all, research it not only about results ... They are ambassadors of a knowledge area, a science.»

\section{Interaction}

The supervisor as well as the doctoral student influenced each other as did the supervisor and the main supervisor. The supervisor also discussed supervisory issues with colleagues. In addition, there was interaction between the supervisor's own experiences of doctoral studies and of receiving research supervision. In the interaction with doctoral students, the latter contributed knowledge in areas that were unfamiliar to the informant. The doctoral students also showed respect for the supervisor's knowledge. Scientific knowledge was tested in interaction with the main supervisor in order to feel secure in this respect when confronting the doctoral students. The informant had experienced negative interaction during own doctoral studies, where an assertive supervisor exerted a negative influence. The importance of understanding the meaning of this phenomenon was expressed in relation to the product.

"It's very important that I can share the supervisory duties and responsibility with somebody.»

«... when I wrote my thesis ... certain encounters hurt me very much and that's something that does not benefit the product.»

\section{Performance of an art}

The informant emphasised that attitude and atmosphere are a part of learning and thus constitute the art of supervision. Attitude meant meeting the doctoral student at the stage of development in which he or she found herself. It included being a good listener, being patient and adapting the supervision in such a way as to give the doctoral student the necessary strength to drive his/her work forward. The supervision sessions invariably commenced with the informant listening to the doctoral students' concerns. The informant exhibited patience by posing questions aimed at helping the doctoral student to arrive at a solution him/herself for the purpose of enhancing the student's trust in his or her own ability.

Attitude was also expressed in terms of respect for the individual. The informant considered it disrespectful and offensive when a supervisor only points out what is not good enough. A better way to make the doctoral student aware of shortcomings is to engage him/her in a discussion on the subject. Respect implies trusting the doctoral student's ability and exhibiting a sense of humanity, which took the form of the informant protecting the doctoral students from being hurt by the academic community and understanding them in their present context.

Atmosphere was described in terms of qualities such as openness and pleasure, which were considered to encourage creativity. An open and friendly atmosphere during seminars etc. was intended to prevent fear of and blockages to creativity.

«...being treated disrespectfully diminishes the product just as it diminishes the human being»

"I have a great deal of patience during the process. Although I can see other possibilities, if they have not yet reached that level, I'll have to wait until they do.

"The academic culture is characterised by sharp elbows, power and struggles. I want to contribute to making it a happy period, because it will reflect on the material that I receive».

\section{Discussion}

The aim of this single subject study was to describe the supervision of doctoral students from the perspective of a research supervisor. Awareness of underlying structures and the prerequisites of learning became visible as self-appraisal, orientation towards a goal, interaction, and performance of an art. In line with Franke (8), the qualitative analysis contributed to a systematisation of experiences, which may be of importance in the communication within research supervision.

\section{Self-appraisal}

Self-appraisal made the awareness of one's own person visible, which Persson (3) describes as one of the most important prerequisites for constructive and communicative supervision. Referring to Selander and Selander, Persson (3) considers that the meaning of supervision is being dependent on somebody else, a fact that can give rise to conflicting emotions in an adult. As all doctoral students are adults and their autonomy develops over the years, entering into a relationship of dependency can result in frustration. A trusting relationship is therefore essential in order to minimise the feeling of dependence. The creation of such a relationship is based on the very fact that the supervisor confronts him/herself and develops good selfknowledge (3).

In this study, awareness of one's motive for being a research supervisor was expressed in terms of stimulation and observing somebody else grow by learning. The results are in line with Lindén (6), who emphasises the importance of the supervisor reflecting over his/her own personal qualities and motives, which is also highlighted by Brockbank and McGill (15). Reflection on one's own and others' actions and seeing actions from different perspectives are vital in all types of relationship. In the supervision of doctoral theses, this translates into the supervisor using reflection to examine how he/she acts, makes assessments, thinks and feels in different supervisory situations. Reflection over actions taken can be based on ethical considerations, questions about what could have been done differently, and what has to be reviewed in the opinion of supervisor and supervisee (16). Reflection makes it possible to critically examine difficult decisions and open up alternative modes of action. Awareness of attitude, ethical values and emotions and their consequences can contribute to the development of professional competence and increased self-confidence. Reflection means critically examining that which is otherwise taken for granted, that which is automatically understood as a matter of course, and that which is usually not problematised (17). Adopting a genuine reflective stance to oneself and others means the time-consuming process of abandoning one's ingrained position and viewing 
the world from another perspective, which can be difficult. Molander (18) argues that reflection means taking a step back in order to observe and ponder over oneself and one's actions with the aim of gaining a perspective on one's situation.

\section{Orientation towards a goal}

The informant was aware of orientation and underlined its importance. The aim was to develop a high-quality product as well as a competent doctoral student. This is in line with The Higher Education Ordinance (4), which states that the education should provide doctoral students with the knowledge and skills necessary to be able to carry out research independently. The doctoral student undergoes a long development process before reaching his/her goal. The supervisor's understanding of what happens during this process is important.

Rossi (19) presents five phases that can explain the process of working through a problem and be applied to the doctoral student's development process. In the first, the perception phase, one becomes aware of the problem and tosses and studies it from different perspectives. The second, the incubation phase, is characterised by stagnation, as no solution seems possible, leading to withdrawal and dejection. Nevertheless, one is actively working through the problem at a subconscious level. The illumination phase represents the breakthrough, during which the Aha-experience emerges, followed by a high level of anxiety and strong emotions. The solution suddenly reveals itself and everything clicks into place. In the verification phase, the student turns somewhat confused, towards the outside world in order to appraise it in the light of his/her new insight. Questions about the consequences and what needs to be reviewed in one's attitude to oneself and the surrounding world come to the fore. If the solution does not hold up to scrutiny or tally, it means returning to the second phase. The fifth and final phase is that of stabilisation, which means that the knowledge has been tested and integrated and the student is satisfied. Rossi's (19) phases can help the research supervisor understand the doctoral student's experiences in the course of the process, which process can, at times, be demanding. It takes a long time for a research supervisor to guide a doctoral student to the stabilisation phase. It does not materialise until the student has successfully defended a thesis i.e. the supervisor has ascertained that the student has passed the finishing line and achieved the goal.

\section{Interaction}

In terms of interaction, both student and supervisor were aware that the exchange of knowledge was mutual, which shows that their relationship was devoid of control and hierarchical thinking. Appel \& Bergenheim (10) also emphasise the exchange of knowledge. All supervisors can learn something about supervision through the interaction with doctoral students, irrespective of whether or not they have prior experience. This exchange begins at the first meeting and continues through the whole supervisory process. The supervisors also learn something about the subject under study, as the student's work adds a certain amount of new knowledge. The informant's previous experience of an assertive supervisor created awareness about what it means when a supervisor exerts control. This phenomenon has been described by, for example, Lindholm (13), who considers that hierarchy and asymmetry are the main characteristics of the supervision process. Holloway and Carrol (20) emphasise that attention should be paid to control and closeness in the interaction between supervisor and student. The research supervisor bears the primary responsibility for ensuring balance.

\section{The performance of an art}

The informant's awareness was visible in her attitude, which provided the necessary conditions for the doctoral students to achieve independence. The informant exhibited awareness in that she saw and understood the student from a holistic perspective and adapted the supervision to suit the person. Understanding people involves the realisation that their present life situation is influenced by the past and by how future prospects are appraised (21). The success of such an attitude may depend on the supervisor's openness to the student and the latter's reaction. Respecting the doctoral student's situation in accordance with a holistic perspective can be one way of reducing stress and freeing creativity. Flexibility in relation to the student's knowledge development creates the conditions necessary for increasing independence in the doctoral work. Meeting each other at the intersection between what the student knows and does not know is important in all learning, most especially when a person is on the way to becoming a researcher. The informant in this study was clearly aware of what was happening within the relationship. Attention was focused on, for example, the doctoral student's vulnerability. Lindholm (13) argues that closeness to the doctoral student places great demands on the supervisor, due to the fact that several aspects of the student's life are involved, such as family, work, financial position and social conditions $(7,13)$. Consequently, supervision of doctoral students influences many people, which means that the supervisor's responsibility is extensive and that the doctoral student is in a vulnerable situation. However, it is essential to set limits in relation to personal aspects but exactly where those limits are set varies according to the individual in question (13). According to Strannegården (22), the student is not only vulnerable in relation to the personal life situation but also due to the fact that each student is working towards a new identity of great importance in terms of emotions and values. The demands on both supervisor and doctoral student are considerable if the relationship is to develop in a satisfactory way. In a good relationship, the student grows, feels secure and develops creativity. Awareness of the doctoral student's vulnerability is one reason for making efforts to create a good supervisor-doctoral student relationship. An important aspect is the feeling that the supervisor believes in the doctoral student's ability (10). Furthermore, respect for personal integrity is a necessary component of the supervision process as well as respect for the individual's own responsibility concerning self and actions. Showing others understanding and love can help a person to grow and develop as a human being. In a supervision model (23), the humanistic perspective is based on the concepts of security, trust, clarity, theory and time. Security can be experienced by drawing up a contract that clearly sets out routines and structure. Trust means mutual acceptance and respect between student and supervisor. The concepts of clarity and time imply that the research issues are made clear to the doctoral student and that sufficient time is allowed for reflection over different perspectives.

Marton and Booth (5) state that the supervisor's awareness is manifested in the ability to adopt the doctoral students' perspective and to evaluate the successfulness of their performance. Awareness concerns adapting one's involvement in line with one's perception of its value in relation to the aim.

This study contributes to the understanding of the qualities involved in research supervision viewed from a supervisor's perspective. The transferability of a single subject study is limited but the result can be of importance in understanding possible underlying structures and preconditions concerning a specific phenomenon. However, more studies in this field are needed. The informant in this study confirmed the reasonableness after reading the result. The trustworthiness was strengthened by comparing the categories to the empirical data and through discussions of this process among the researchers as well as by the quotations supporting the analysis.

\section{Conclusion}

The aim was to describe supervision from the perspective of a research supervisor. The research supervision had a latent content of awareness of underlying structures and the preconditions for learning, which became visible in the supervisor's appraisal of herself as well as in the orientation towards a goal, interaction and the performance of an art. Awareness was a cornerstone in research supervision that enabled both the what and the how aspect of learning. Supervisor experiences and theories is a base for development of research supervision within nursing 
Accepted for publication 20.08.2007.

Evy Lidell RNT, PhD School of Social and Health Sciences, Halmstad University, Sweden

Cathrine Hildingh RNT, PhD School of Social and Health Sciences, Halmstad University, Sweden

Barbro Arvidsson RNT, PhD School of Social and Health Sciences, Halmstad University, Sweden. Faculty of Nursing Science, Gjövik University College, Gjövik, Norway

Corresponding author:

Evy Lidell, School of Social and Health Sciences, Halmstad University, Campus Varberg, Otto Torells gata 16, 43280 Varberg E.mail: Evy.Lidell@hos.hh.se, Phone: +46 35167457

\section{References}

1. Thompson DR, Kirkman S, Watson R, Stewart S. Improving research supervision in nursing. Nurse Educ Today 2005;25:283-290.

2. Fridlund B. 10 challenges in supervision of doctoral students. Editorial Eur J Cardiovasc Nurs 2005;4: 97-98.

3. Persson RS. Vetenskaplig handledning (Research supervision). Lund: Studentlitteratur; 1999 (In Swedish).

4. SFS 1992: 1434. Nya högskolelagen. (The New Higher Education Act) Stockholm: Utbildningsförlaget; 1992.

5. Marton F, Booth S. Learning and awareness. New Jersey: Lawrence Erlbaum Associates, Inc; 1997.

6. Lindén J. Handledning av doktorander. (Supervision of doctoral students). Nora: Nya Doxa; 1998.

7. Bergenheim Å. Inspirationskälla, föredöme, tränare och kollega. Forskarhandledares visioner och verklighet. (Source of inspiration, role model, coach and colleague. Research supervisors' visions and reality).Umeå: Universitetspedagogiskt centrum. Umeå University, Skriftserie från Universitetsförvaltningen 2001:1; 2001 (In Swedish).

8. Franke A. Olika sätt att erfara doktorandhandledning - en studie med doktorandhandledare. (Different ways of experiencing research supervision - a study of research supervisors) (IPD-rapporter 2002:06). Gothenburg: Göteborg University, department of pedagogics and didactics, Gothenburg; 2002 (In Swedish).

9. Apel M. Forskarhandledning: Möte med vandrare och medvandrare på vetenskapens vägar. (Encounters with travellers and co-travellers on the paths of science) Högskoleverkets rapportserie 2003:26R (In Swedish).

10. Appel M \& Bergenheim Å. Reflekterande forskarhandledning. Om samarbetet mellan handledare och doktorand. (Reflective research supervison. On the subject of cooperation between supervisor and doctoral candidate). Lund: Studentlitteratur; 2005 (In Swedish).

11. Lindén J. Ethics in supervising doctoral students. Nordisk Pedagogik 2005:25; 229-244. (In Swedish).

12. Hessle A. Legitimitetstrappan. En modell för kunskapsformation i forskarutbildningen. (The legitimacy ladder. A knowledge development model in research education) Rapport Socialt arbete $\mathrm{nr}$ 31. (Social work report, no. 31). Stockholm: Stockholm University, Department of social work;1987(In Swedish).
13. Lindholm S. Forska och skriva- En liten vägledning. (Researching and writing - A short guide). Lund: Academia Adacta AB; 1999 (In Swedish).

14. Graneheim UH, Lundman B. Qualitative content analysis in nursing research: Concepts, procedures and measures to achieve trustworthiness. Nurse Educ Today 2004:24;105-112.

15. Brockbank A, McGill I. Reflective learning in higher education. Society for Research into Higher Education \& Open University Press; 1998.

16. Johns C. Professional supervision. J Nurs Manag 1993:1;9-18.

17. Schön D. Educating the reflective practitioner. San Francisco: Jossey-Bass Publishers; 1987.

18. Molander B. Kunskap i handledning (Knowledge of supervision). Gothenburg: Bokförlaget Daidalos; 1993 (In Swedish).

19. Rossi E. The breakout heuristic: a phenomenology of growth therapy with college students. J Human Psychol 1968: 8;16-28.

20. Holloway E, Carroll M. Training counselling supervisors. London: Sage Publications; 1999.

21. Bengtsson J. Sammanflätningar. (Intertwinnings). Gothenburg: Bokförlaget Daidalos; 1988 (In Swedish).

22. Strannegården L. Avhandlingen. Om att formas till forskare. (The thesis. The formation of a researcher). Lund: Studentlitteratur; 2003

23. Arvidsson B. Clinical supervision: A study of how psychiatric nurses experience group supervision. (Educational and Psychological Interactions, 123). Malmö: School of Education; 2000. 